\title{
A CONTRIBUTION TO HUMAN GEOGRAPHICAL REGIONALISATION OF THE CZECH REPUBLIC AT THE MEZZO LEVEL
}

\section{Př ÍSP'rVEK K HUMÁNN'nGEOGRAFICKÉ REGIONALIZACI LESKÉ REPUBLIKY NA MEZOÚROVNI}

\author{
doc. RNDr. Marián HALÁS, Ph.D. ${ }^{1}$ \\ Mgr. Pavel KLAPKA, Ph.D. ${ }^{1}$ \\ Mgr. Petr TONeV, Ph.D. ${ }^{2}$

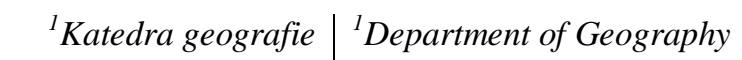 \\ PŚrodovnlecká fakulta Faculty of Science \\ Univerzita Palackého v Olomouci Palacký University Olomouc \\ $\bowtie$ 17. listopadu 12, 77146 Olomouc, Czech Republic \\ E-mail:marian.halas@upol.cz,pavel.klapka@upol.cz
${ }^{2}$ Katedra regionální ekonomie a správy ${ }^{2}$ Depart. of Regional Economics and Administration
Ekonomicko-správní fakulta Faculty of Economics and Administration
Masarykova univerzita Masaryk University
$\triangle$ Lipová 41 a, 60200 Brno, Czech Republic
E-mail: tonev@econ.muni.cz

\begin{abstract}
Annotation
The coreï periphery dichotomy belongs among the basic axioms of the spatial organisation of society. It exists at various hierarchical levels. It forms basis for human geographical regionalisations, when resulting functional (or just nodal) regions have their central and peripheral areas. For the territory of the Czech Republic is typical that the most distinct peripheries concentrate along the boundaries of the spheres of influence of regional centres at the level of regional capitals. The main objective of this contribution is to propose the regionalisation of the Czech Republic at the mezzo regional level (i.e. the level corresponding to the primary dichotomic distribution of core and periphery), to compare it to existing regionalisations at the mezzo regional level, and to confront the boundaries of resulting regions with localisations of peripheral areas.
\end{abstract}

Key words

dichotomy coreï periphery, travel-to-work flows, regional division, Czech Republic

\section{Anotace}

Dichotomie jádroï periférie patŚ mezi základní axiómy prostorového uspoŚádání spole!̣ nosti. Existuje na rTzných hierarchických úrovních. Vycházejí z ní i humánnクgeografické regionalizace, kdy mají výsledné funk! ní (nebo jen nodální) regiony svoje jádrové i periferní |ásti. Pro území L eské republiky

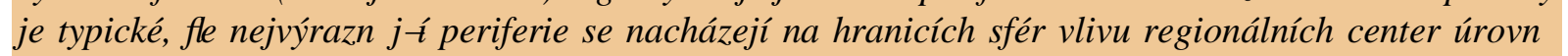

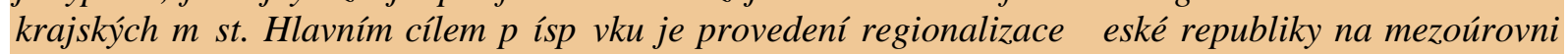
(t. j. úrovni odpovídajicí primárnímu dichotomickému rozloǵení jádroï periferie), porovnání s dosavadními ostatními regionalizacemi na mezoúrovni a konfrontace hranic výsledných regionT s lokalizací periferních území.

\section{Klị ová slova}

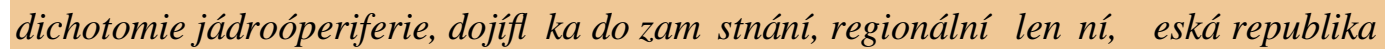


JEL classification: J01, J40, R10, R12

\section{Introduction}

Geographic space is not homogenous, its constituent elements are distributed in an uneven manner, i.e. they are represented in various regions with different intensity. In most cases there is a natural tendency toward balance in the differences. This balancing by means of spatial flows and interactions cannot bring the total homogeneity and a certain level of differences in social and economic characteristics (existence of developed and less developed areas) or in central and peripheral regions is natural and belongs among basic axioms of spatial organisation. These differences contribute to the spatial organisation of society at various hierarchical levels.

For the territory of the Czech Republic is typical that the most distinct peripheries concentrate along the boundaries of the spheres of influence of regional centres at the level of regional capitals. The main objective of this contribution is to propose the regionalisation of the Czech Republic at the mezzo regional level (i.e. the level corresponding to the primary dichotomic distribution of core and periphery), to make comparisons and confrontation of boundaries of resulting regions with localisations of peripheral areas. The only published regionalisation at mezzo level after 2000 (Hampl, 2005) will be included in the comparisons as well.

\section{Corel̈ periphery dichotomy}

The issue of peripheral regions and research of the coreï periphery relationship is a long term subject matter for many authors. Within the International Geographical Union it has been in the centre of the attention of the Study Group on Development Issues in Marginal Regions, and the Commission on Dynamics of Marginal and Critical Regions dating back to 1980, when within the Commission on Rural Development the Subcommission on High-latitudes and Mountain Regions had been established (Majoral et al., 1998). The group has produced a number of proceedings and contributions on peripheral areas (e.g. Chang-Yi et al., 1994; Jusiila et al., 1998; Majoral et al., 2000; Valença et al., 2008). Schmidt (1998) with respect to hierarchy reminds that position of each region on the coreï periphery scale is dependent on hierarchical scale and on comparisons determined by this scale. She documents the multiscalarity of the coreï periphery concept by the frequently posed questions, whether it is better to be a periphery in a core, or a core in a periphery.

The recently rapidly development research of peripheral regions in the Czech Republic and Slovakia is documented by a number of projects and publications (Havlí! ek et al., 2005; Musil, Müller, 2006, 2008; Dǵupinová et al., 2008; Halás, 2008; Rosina, Hurbánek, 2013). The crucial delimitation of peripheral regions in the Czech Republic was proposed by Musila and Müller (either pioneering work from the 1980s ï Musil, 1988 or more recent works ï Musil, Müller, 2006, 2008). These works use so called general units as basic spatial units for spatial analyses. There are 1000 or so general units and each consists of six municipalities in average. The general units comprise the municipalities with basic central function (they have a post office, school, health centre, building office and registry office) and their hinterlands. The work of Matyág et al. (2007), which is based also on the general units (Müller was the team member as well), will be used in this contribution for a comparison to human geographical regionalisation. Spatial pattern of peripheral regions is logically very similar to all the above-mentioned outputs.

\section{Theoretical foundations and method}

There are several works addressing the delineation of human geographical regions at the lowest hierarchical level (i.e. micro level), either simple nodal regions (Hampl, 2005; Sýkora, Mulí! ek, 2009; Halás et al., 2010) or more sophisticatedly delineated functional regions (Klapka et al., 2013). However, there is, until now, the only recent publication addressing the human geographical regions at 
the mezzo level (Hampl, 2005), where its author follows his earlier publications based on the analysis of commuting flows for respective censuses. Unlike the micro regional level based on the daily labour commuting he uses the total daily and non-daily labour and school commuting for delineation of mezzo regions. Methodical explanation of the regionalisation procedure is not very detailed, but the author claims that he used only the flows among towns that are also centres at the lower level, not the total flows (addition of daily and non-daily flows can be possibly considered as being methodologically problematic, they are actually completely different processes). As mezzo regional centres he identifies all regional capitals with the exception of Jihlava. Resulting human geographical regions at mezzo level is presented in fig. 2 a.

This contribution tries to put forward an alternative to the above-mentioned approach and findings. It remains a question whether complex human geographical regions at mezzo level can be determined by total labour and school commuting. Another question concerns a set of mezzo regional centres. If such towns as Karlovy Vary or Zlín belong, it seems necessary to include Jihlava as well (more details in Halás, 2010). However, these hypotheses have to be verified and supported by relevant evidence.

Coming out of a theoretical axiom of coreï periphery dichotomy it is quite clear that when delineating functional (or nodal) regions the peripheries have to be located near the boundaries of regions, i.e. along the boundaries of spheres of influence of regional centres. Since the mezzo regional centres seem to play a major role in the Czech Republic in this respect, peripheral regions are located along the boundaries of the spheres of influence of these centres, which generally represent the level of regional capitals. It can be further suggested that the dominant interaction determining spatial organisation at the mezzo regional level does not lie in the total labour and school commuting but that it is daily commuting flows, and preferably labour commuting flows, that are of importance. A distance-decay function can be used to model the decrease in intensity of these flows. Boundaries of human geographical regions can be determined by the identification of break points between the spheres of influence for respective mezzo regional centres (fig. 1) and the resulting mezzo regions are defined. The set of mezzo regional centres includes Jihlava (see above), Hradec Králové and Pardubice organise one polycentric region, and individual distance-decay functions for all mezzo regional centres are adopted from Halás et al. (2014). The procedure is analogical to the work of Halás and Klapka (2010), including the role of secondary centres for mezzo regions of Ústí nad Labem and Ostrava, and functional regions defined by Klapka et al. (2013) serve as basic spatial unit for the analysis.

Fig. 1: Identification of boundary of nodal region by distance-decay function

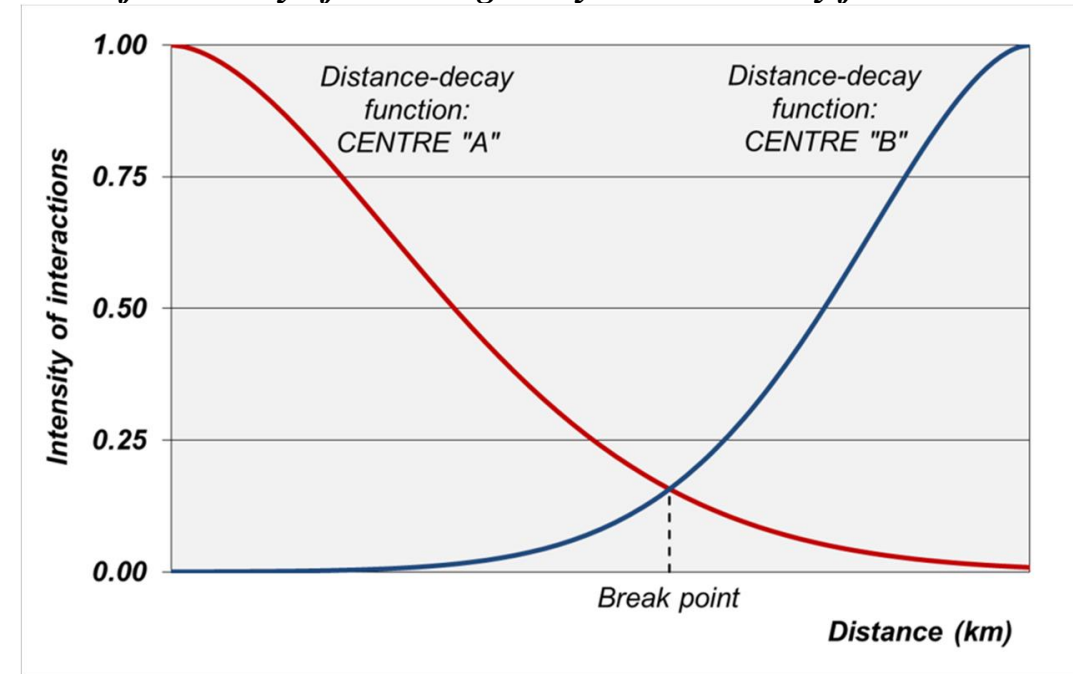

Source: authors'elaboration. 


\section{Results}

Delineation of resulting human geographical regions at the mezzo level is presented in fig. $2 \mathrm{~b}$. Resulting regional pattern characterises very well regular coexistence of dominant Prague with the regions of PlzeŔ L eské Bud Dovice, Liberec and others along the outer rim of Bohemia, and relatively contrasting relations, which are typical of adequate mezzo regional centres in Moravian-Silesian space. The region of Jihlava fills up adequately space between Prague and Brno. A boundary between mezzo regions of Brno and Jihlava is somewhat problematic, since the micro regions of TŚbí! and Velké MeziŚlí (serving as basic spatial units in this analysis) stretch from west to east. Specific geographical factors are responsible for that. In the former case it is the existence of nuclear power station in Dukovany attracting considerable number of labour commuting flows, in the latter case it is the existence of D1 motorway forming the axis of the Velké MeziŚcí region and acting as a factor deforming the space. Actually the western parts of both regions incline to Jihlava and eastern parts to Brno.

The regional pattern of the resulting mezzo regions layered over the peripheral areas (fig. 4) confirms both hypotheses made above. The resulting boundaries of human geographical regions at the mezzo level coincide with the localisation of peripheries. Meandering boundaries expressing ambiguity in the mezzo regional affinity of areas occur most distinctly in the area of so called inner peripheries of Bohemia (east of Doupovské hory Mts., between towns of PŚbram, HoraǵNovice, Tábor and Písek etc.). The existence of the region of Jihlava seems to be reasonable as well. This centre forms adequate hinterland and should be included in the set of mezzo regional centres.

On the contrary, the boundaries of human geographical mezzo regions proposed by Hampl (2005) do not correlate with the pattern of peripheral regions. It is best witnessed in case of the regions of L eské Bud Dovice and Liberec. Leaving out of Jihlava from mezzo regional centres also does not appear very well founded. The boundary between spheres of influence of Prague and Brno intersects the Vysol ina region into two parts, while the delineation of peripheral regions according to Matyág et al. (2007 ï fig. 3) show that the Vysol ina region has both its central and peripheral areas.

Fig. 2: Human geographical mezzo regions of the Czech Republic according to total commuting flows (a), and distance-decay function based on daily travel-to-work flows (b)
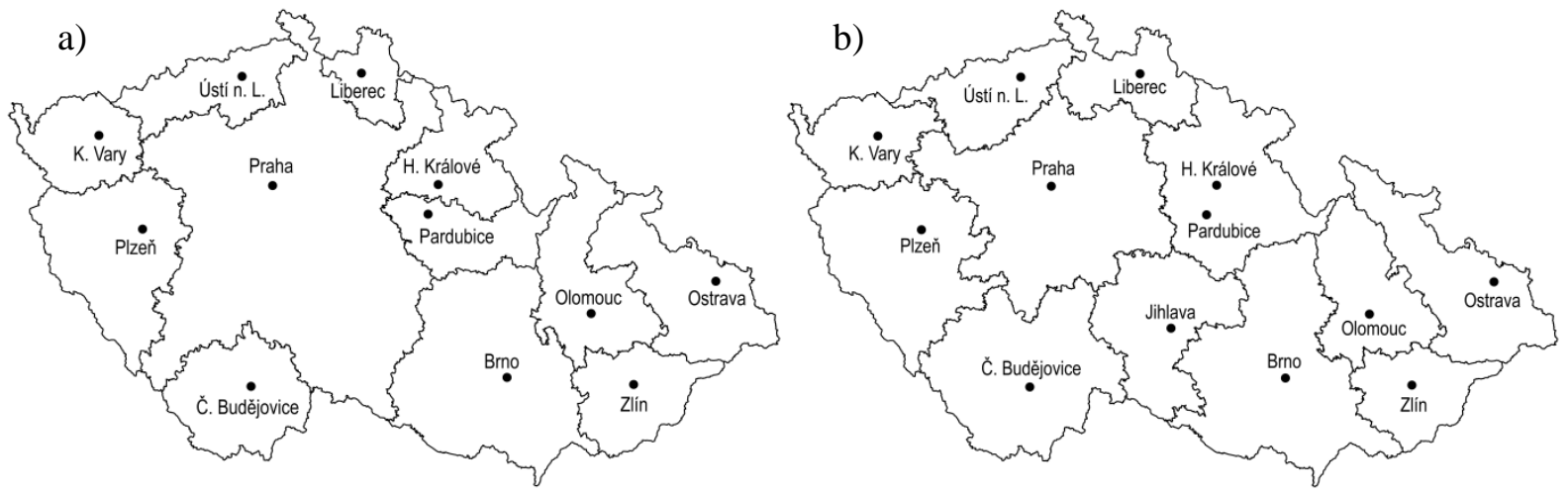

Source: Hampl, 2005; authors' elaboration. 
Fig. 3: Human geographical mezzo regions of the Czech Republic according to total commuting flows vs. peripheral areas

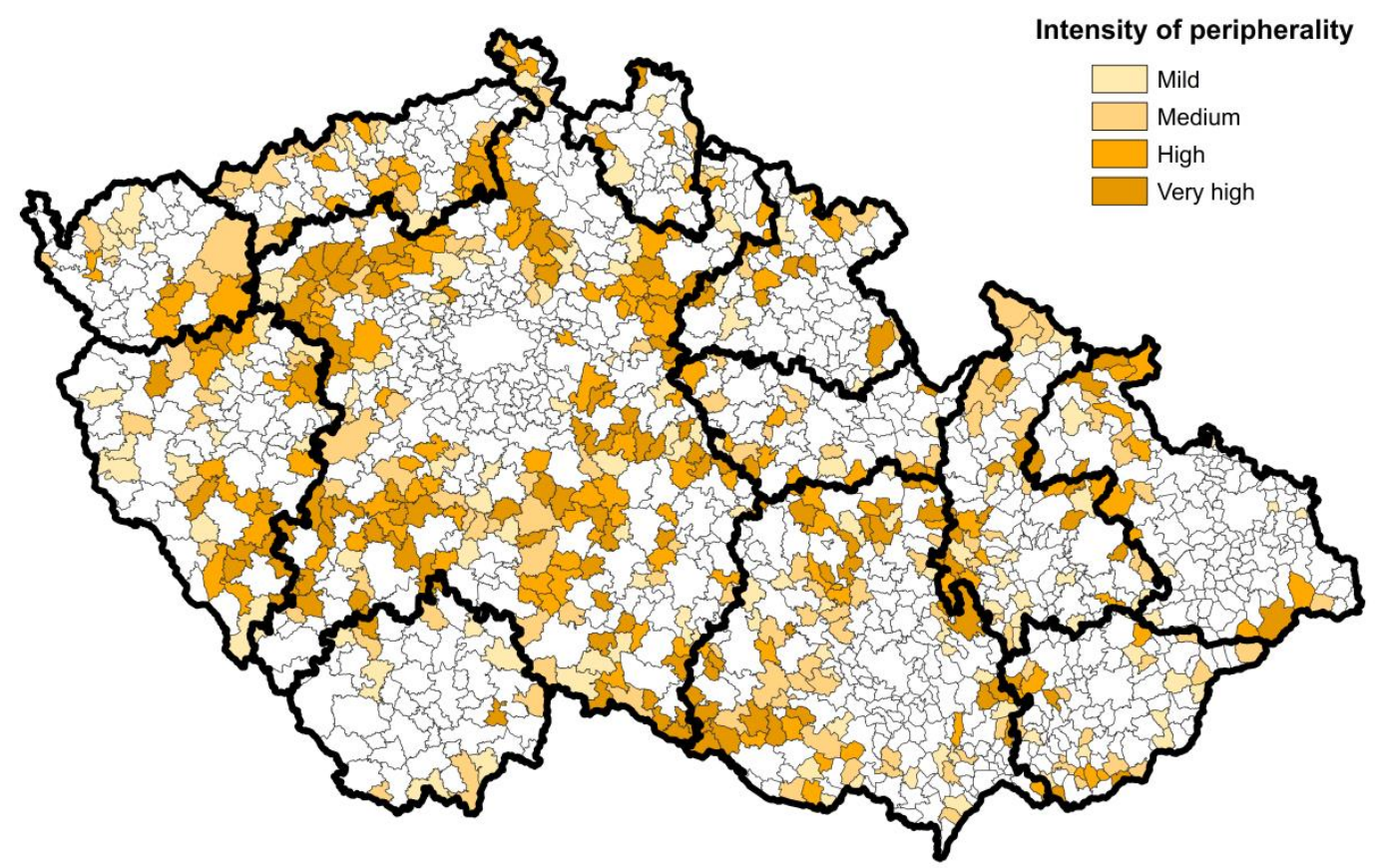

Source: Matyáǵet al., 2007; Hampl, 2005; authors'elaboration.

Fig. 4: Human geographical mezzo regions of the Czech Republic according to distance-decay function vs. peripheral areas

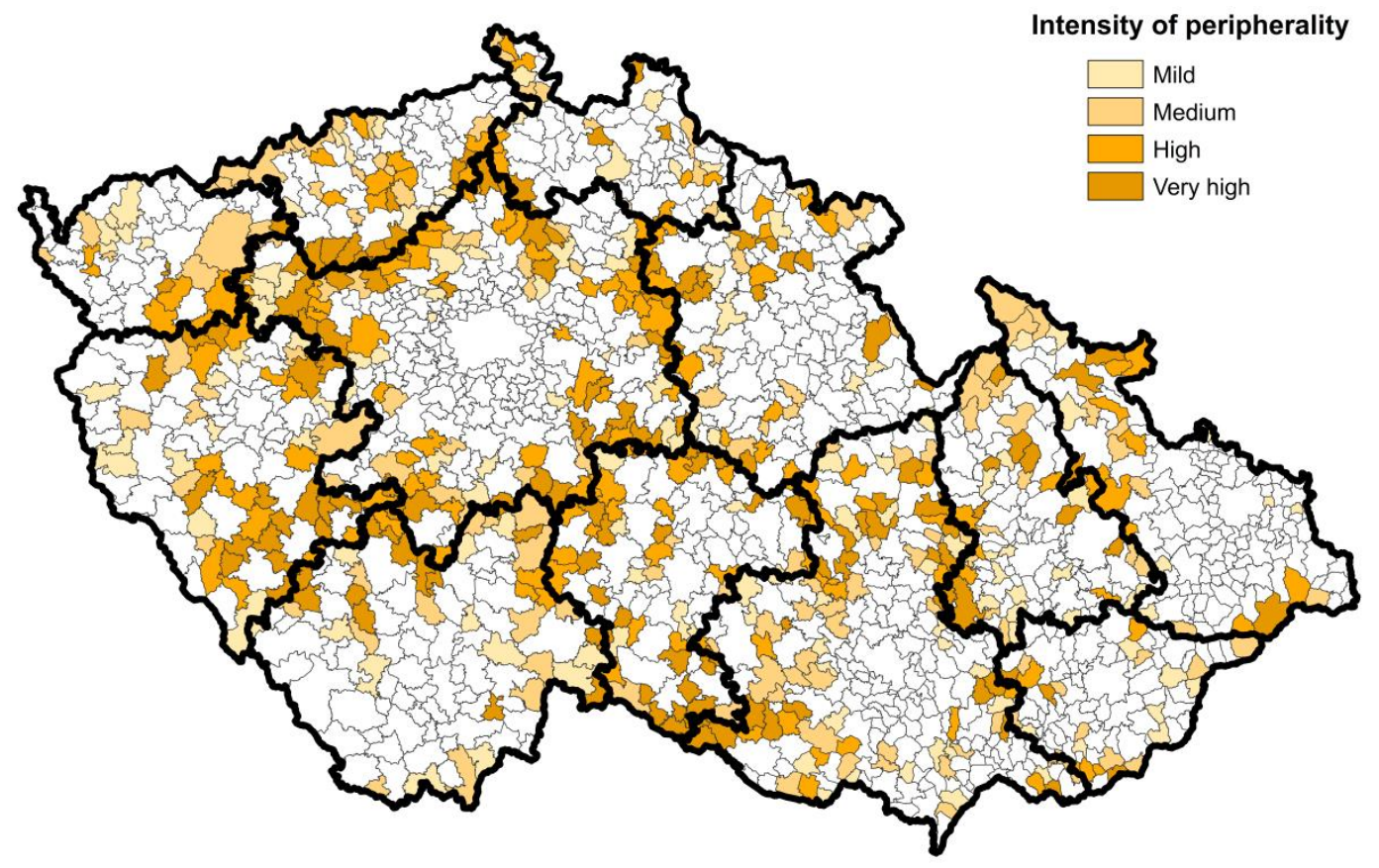

Source: Matyáǵet al., 2007; authors' elaboration.

\section{Conclusion}

The contribution has attempted to verify the hypothesis that boundaries of human geographical regions at the mezzo level coincide with localisation of peripheral areas. This hypothesis has been confirmed and it has also been shown that dominant process determining the organisation of regional and settlement systems is daily labour commuting both at micro and mezzo levels. It can be concluded that sum for daily and non-daily interaction flows is not very suitable for delineation of human 
geographical mezzo regions, which would be denoted as complex regions (i.e. expressing general spatial organisation of society). Non-daily labour commuting flows can be processed separately for sure, but their analysis has shown that they determine the highest (macro regional) level of spatial differentiation, where Prague is the only dominant centre. Non-daily school commuting flows are limited to a very specific population segment (predominantly university students, to a lesser extent also secondary school students, i.e. the age group 15-25 years).

If a mezzo level regionalisation based on different process were to be carried out, the resulting regions could be correctly defined, but they cannot be called complex human geographical regions. Further on, it appears that Jihlava is a full-bodied mezzo regional centre comparable to Karlovy Vary or Zlín and forms adequate hinterland. Distribution of peripheral areas is determined always by the location at the rim of functional regions with greater distance or bad accessibility to regional centres. In the Czech Republic the centres occur at the mezzo level and include all regional capitals.

\section{References}

[1] CHANG-YI, D. C., SUE-CHING J., YIN-YUH, L. (eds.), (1994). Marginality and development issues in marginal regions. Proceedings of study group on development issues in marginal regions. Taipei: National Taiwan University.

[2] DG̣UPINOVÁ, E., HALÁS, M., HORœÁK, M., HURBÁNEK, P., KÁḶEROVÁ, M., MICHNIAK, D., ONDOG S., ROCHOVSKÁ, A., (2008). PeriférnosŠ a priestorová polarizácia na území Slovenska. Bratislava: Geo-grafika.

[3] HALÁS, M., (2008). Priestorová polarizácia spoloḷ nosti s detailným pohădom na periférne regióny Slovenska. Sociologický ! asopis / Czech Sociological Review, vol. 44, iss. 2, pp. 349-369. DOI $10.2307 / 41132580$

[4] HALÁS, M., (2010). Should Jihlava be a county town? In Geografie pro ğivot ve 21. století. Ostrava: Ostravská univerzita, pp. 641-645.

[5] HALÁS, M., KLADIVO, P., ĠMÁLEK, P., MINTÁlOVÁ, T., (2010). Delimitation of micro-regions in the Czech Republic by nodal relations. Moravian Geographical Reports, vol. 18, iss. 2, pp. 16-22.

[6] HALÁS, M., KLAPKA, P., (2010). Regionalizace L eska z hlediska modelování prostorových interakcí. Geografie, vol. 115, iss. 2, pp. 144-160.

[7] HALÁS, M., KLAPKA, P., KLADIVO, P., (2014). Distance-decay functions for daily travel-to-work flows. Journal of Transport Geography, vol. 35, pp. 107-119. DOI 10.1016/j.jtrangeo.2014.02.001.

[8] HAVLÍl,EK, T., CHROMÝ, P., JANL ÁK, V., MARADA, M., (2005). Vybrané teoretickometodologické aspekty a trendy geografického výzkumu periferních oblastí. In Problémy periferních oblastí. Praha: Univerzita Karlova, , pp. 6-24.

[9] JUSSILA, H., LEIMGRUBER, W., MAJORAL, R. (eds.), (1998). Perception of marginality: theoretical issues and regional perceptions of marginality in geographical space. Aldersrot: Ashgate.

[10] KLAPKA, P., HALÁS, M., TONEV, P., BEDNÁř , M., (2013). Functional regions of the Czech Republic: comparison of simple and advanced methods of regional taxonomy. Acta Universitatis Palackianae Olomucensis, Facultas Rerum Naturalium, Geographica, vol. 44, iss. 1, pp. 45-57.

[11] MAJORAL, R., JUSSILA, J., DELGADO-CRAVIDÃO, F. (eds.), (2000). Globalization and marginality in geographical space: Political, economic and social issues of development in the new millennium. Aldershot: Ashgate.

[12] MAJORAL, R., LEIMGRUBER, W., JUSSILA, J., (1998). Introduction. In Perception of marginality. Aldersrot: Ashgate, pp. 1-5.

[13] MATYÁĠ F., KLÍMA, J., MÜLleR, J., PTÁLEK, P., TOUĠEK, V., (2007). Dopady popula!̣ího vývoje pro strategii rozvoje region丁. Záv円e!̣ ná zpráva projektu MMR. Olomouc: Univerzita Palackého v Olomouci, Praha: ÚRS.

[14] MUSIL, J., (1988). Nové pohledy na regeneraci nağch m\$şt a osídlení. Územní plánování a urbanismus, vol. 15 , iss. 2, pp. 67-72.

[15] ROSINA, K., HURBÁNEK, P., (2013). Internet availability as an indicator of peripherality in Slovakia. Moravian Geographical Reports, vol. 21, iss. 1, pp. 16-24. DOI 10.2478/mgr-2013-0002.

[16] SCHMIDT, M. H., (1998). An integrated systematic approach to marginal regions: from definition to development policies. In Perception of marginality. Aldersrot: Ashgate. pp. 45-66.

[17] SÝKORA, L., MULÍLEK, O., (2009). The micro-regional nature of functional urban areas (FUAs): Lessons from the analysis of Czech urban and regional system. Urban Research and Practice, vol. 2, iss. 3, pp. 287-307. DOI 10.1080/17535060903319228 
[18] VALENÇA, M., NEL, E., LEIMGRUBER, W, (2008). The global challenge and marginality. New York: Nova Science.

This work was supported by the Internal Grant Agency of the Palacky University Olomouc under Grant Human behaviour and activities in geographical environment: analysis and modelling of the organisation of space [number IGA_PrF_2014012]. 